
ISSN : 2615-1995, E-ISSN : 2615-0654

J. Madani., Vol. 2, No. 1, Maret 2019 (51 - 68)

C2018 Lembaga Kajian Demokrasi

MADANI

dan Pemberdayaan Masyarakat (LKD-PM)

\title{
MODERNISASI PENDIDIKAN PESANTREN PERSPEKTIF NURCHOLIS MADJID
}

\author{
Mudzakir \\ Fakultas Tekhnik, Universitas Pamulang \\ irul0706@yahoo.co.id
}

\begin{abstract}
Abstrak
Berbicara tentang modernisasi pendidikan pesantren, maka harus kita ketahui kenapa pendidikan pesantren memerlukan modernisasi, sebagai sebuah lembaga yang mempunyai sejarah panjang di Indonesia kenapa harus menerapkan konsep modernisasi ini. Serta harus ada keselaraan dengan pendidikan pesantren dengan perkembangan zaman, agar bisa memahami perkembangan dan kemajuan maka harus melihat pristiwa pada masa lalu apa yang terjadi dengan dunia pendidikan pesantren. Diantara tokoh pembaharuan pendidikan pesantren, sosok Nurcholis Madjid adalah salah satu pembaharu yang berani meyuarakan ide, konsep dan pemikirannya yang dinilai kontroversi, kurang terbuaknya pesantren terhadap perkembangan zaman cak Nur mencoba memberikan masukan kepada pendidikan pesantren agar tetap eksis dan berkembang sampai akhir zaman yang pada akirnya mengarah kepada perbaikan system pendidikan pesantren. Dalam penelitian ini berisi beberapa indikator dengan rumusan masalah. Bagaimana modernisasi pendidikan pesantren perspektif Nurcholish Madjid yang mana penelitian ini berupa penelitian kajian pustaka dengan menggunakan pendekatan rasional dan dari berbagai sumber data, serta untuk mendapatkan data yang valid tentunya dengan beberapa acuan-acuan peneliti terdahulu guna membimbing peneliti agar tidak melenceng serta untuk melanjutkan penelitian yang telah ada terdahulu. Walhasil penelitian ini menunjukkan bahwa konsep dan kontribusi pemikiran Nurcholish Madjid mencakup tentang pendidikan pesantren dan bagaimana relevansinya di zaman modern sekarang ini, dengan tetap melestarikan dan mempertahankan budaya dan tradisional pesantren sebagai ciri khas Islam keIndonesiaan, serta memadukannya dengan berbagai hal baru yang lebih baik. Seperti harapan para ulama" terdahulu "al-muhafadlotu ala qodimi al-sholih wa al-akhdlu bi al-jadidi al-ashlah".
\end{abstract}

Kata Kunci: Modernisasi, Pendidikan Pesantren Nurcholish Madjid.

\begin{abstract}
Talking about modernization of Islamic boarding school education, we must know why it needs modernization, as an institution that has a long history in Indonesia, why should we apply this concept of modernization. As well as having to be in line beteewn it education with the times, in order to understand development and progress, it must be seen in the past what happened to the world boarding school education. Among the leaders of the pesantren education reformation, Nurcholis Madjid was one of the reformers who dared to express his ideas, concepts and thoughts which were considered controversial, because of only a few Islamic boarding school that why the lack of the pesantren to the development of cak Nur tried to provide input about Islamic boarding school education to exist and develop until the end of time leads to the improvement of the Islamic boarding school education system. In this study contains several indicators with the formulation of the problem. How is the modernization of Islamic boarding school education in the perspective by Nurcholish Madjid, perspectuve this research is an library research using a rational approach and from various data sources, as well as obtaining valid data, of course, with some previous researchers' references to guide researchers so that they do not deviate and continue research there has been a past. The results of this researh indicates that the concept and contribution of Nurcholish Madjid's thinking covers the education of Islamic boarding school and how it is relevant in modern times, while preserving and maintaining the culture and traditional Islamic boarding school as a characteristic of Islam culture in Indonesia, and combining it with new and better things. Like the expectations of the previous ulama 'al-muhafadlotu ala qodimi al-sholih wa al-akhdlu bi al-jadidi al-ashlah (main taining a long good, and
\end{abstract}


talking a new one better)

Keywords : Modernization, of Islamic Boarding School Education Nurcholish Madjid perspektive

\section{PENDAHULUAN}

\section{Latar Belakang}

Pendidikan adalah segala sesuatu yang universal dan berlangsung terus menerus yang tak pernah putus dari generasi ke generasi di manapun di dunia ini. Upaya memanusiakan manusia melalui pendidikan itu diselenggarakan sesuai dengan pandangan hidup dan dalam latar belakang sosial kebudayaan masyarakat tertentu. Sejak manusia menghendaki kemajuan dalam kehidupan maka sejak itu timbul gagasan untuk melakukan penggalian, pelestarian, dan pengembangan kebudayaan melalui pendidikan. Pendidikan berperan aktif dalam kehidupan masyarakat untuk mencapai apa yang telah dicita-citakan oleh masyarakat sebagai penerus bangsa, yang mana dalam hal ini menjadi tugas bagi para pembaharu pendidikan dalam membantu memenuhi kebutuhan masyarakat demi tercapainya cita-cita tersebut. Masyarakat sebagaimana dikatakan Ary H. Gunawan, memiliki fungsi sebagai penerus budaya dari satu generasi ke generasi selanjutnya. Proses ini berlangsung secara dinamis, sesuai dengan situasi dan kondisi serta kebutuhan masyarakat. Media untuk alih budaya ini adalah pendidikan dan interaksi sosial.

Dalam kerangka ini, pendidikan dapat diartikan sebagai proses sosialisasi, yaitu sosialisasi nilai, pengetahuan, sikap, dan keterampilan antar generasi. Fenomena inilah yang harus menciptakan sistem pendidikan yang kondusif, karena perkembangan masyarakatlah yang menghendaki adanya pembinaan peserta didik yang menghubungkan antara ilmu dan amal, asas pendidikan itulah yang akan lebih dibutuhkan di tengah-tengah masyarakat serta mampu menyesuaikan diri pada lingkungan sosialnya. Pendidikan memiliki kaitan erat dengan setiap perubahan sosial, baik berupa dinamika perkembangan individu maupun proses sosial dalam skala yang lebih luas.

Secara tegas, Muhammad Abduh, sebagaimana dikutip Tibawi, mengatakan bahwa pendidikan adalah alat yang ampuh untuk melakukan perubahan. Pendidikan, bisa melakukan sebuah perubahan yang sangat luar biasa apabila orang-orang yang mempunyai kepentingan bisa menjalankan fungsi dan tugasnya secara maksimal dengan memberikan terobosan yang dapat mengangkat pendidikan lebih berguna lagi di tengah-tengah masyarakan tempat dimana mereka bersosialisasi dengan lingkungan. Menurut A. Malik Fadjar, dalam masyarakat akhir-akhir ini terjadi adanya pergeseran pandangan terhadap pendidikan, seiring dengan tuntutan masyarakat (social demand) yang berkembang dalam skala yang lebih makro. Menurutnya, kini masyarakat melihat pendidikan tidak lagi dipandang hanya sebagai bentuk pemenuhan kebutuhan terhadap perolehan pengetahuan dan keterampilan dalam konteks sekarang.

Oleh karena itu upaya pencegahan adanya pergeseran pemahaman masyarakat terhadap esensi pendidikan oleh para pembaharu pendidikan adalah dengan mengadopsi gagasan, pemikiran, dan pendapat dari para pemikir pendidikan masa lalu, untuk memberikan simpulan-simpulan baru dalam memahami pendidikan dalam negeri. Pendidikan yang sesuai dengan kebutuhan masyarakat dan dapat memberikan kemampuan secara teknologis, fungsional, individual, informatif, dan terbuka. Dan lebih penting lagi kemampuan secara etik dan moral yang dapat dikembangkan melalui pendidikan dan agama. Pendidikan dan Agama memiliki kesinambungan yang sangat erat sebagaimana eratnya hingga satu dari keduanya saling melatarbelakangi, dan Indonesia sebagai negara yang mayoritas penduduknya beragama Islam, amat kaya dengan pertumbuhan dan perkembangan lembaga pendidikan Islam, dan tumbuh didalamnya dinamika pertumbuhan lembaga-lembaga pendidikan Islam yang melahirkan generasi pembaharu.

Nurcholish Madjid merupakan figur yang kontroversial, terbukti dari keberaniannya dalam mengungkapkan segala gagasan baik di media massa maupun dalam berbagai seminar, serta semangat Nurcholish Madjid beserta rekanrekannya dalam membangun bangsa Indonesia untuk dapat lebih maju serta dapat mengikuti perkembangan zaman, karena modernisme yang menurut penulis semakin menjadikan sebuah kebutuhan adalah sesuatu hal yang niscaya. Untuk itu, Nurcholish Madjid menawarkan gagasan baru tentang bagaimana cara menyingkapi suatu perubahan yang jika tidak disadari dari awal maka akan menjauhkan manusia dari hakikatnya. Banyak sekali ide yang di lontarkan oleh cak Nur, khususnya setelah pulang dari Amerika Serikat. Ia mengatakan bahwa kalau kita pemimpin atau seorang pemimpin kita harus seperti lokomotif bagian dari kereta api, yang tidak di tarik oleh gerbong-gerbongnya lokomotiflah yang harus menarik gerbonggerbongnya, pemimpin harus menarik umat kearah yang lebih baik.

Adapun tema pokok dari pemikiran cak Nur pada umumnya dilontarkan pada masalahmasalah keterbukaan, kebebasan, aktifisme 
positif, keniscahyaan untuk membumikan ajaran Islam, dan keharusan untuk menyesuaikan aturan-aturan hidup dengan perubahanperubahan sosial tanpa mengakhiri atau justru untuk menegaskan kembali pesan-pesan Islam. Kiranya tidak berlebihan jika pernyataan di atas dikaitkan dengan apa yang pernah dikatakan tokoh LSM Dawam Raharjo, yang menyebutkan bahwa orang-orang yang berpendidikan Barat semacam Nurcholish Madjid, memperkenalkan gagasan-gagasan modernisasi Fazlur Rahman. Segala bentuk perbincangan tokoh-tokoh semacam Nurcholish Madjid menurut Dawam sangat membentuk citra kecendekiawaan Muslim di samping mempengaruhi alam pikiran Islam Indonesia.

Sebagai lembaga pendidikan Islam tertua di Indonesia, pesantren tetap saja menarik untuk dikaji dan ditelaah kembali. Pesantren adalah salah satu lembaga pendidikan Islam yang mempunyai kekhasan tersendiri dan berbeda dengan lembaga pendidikan lainnya. Kemandirian, keikhlasan dan kesederhanaan merupakan nilai-nilai yang dapat melepaskan dari dampak negatif globalisasi dalam bentuk ketergantungan dan hidup konsumerisme yang lambat tapi pasti akan menghancurkan sendi-sendi kehidupan umat manusia.

Persoalannya adalah bagaimana mengembangkan dan melabuhkan nilai-nilai tersebut dalam hidup keseharian, serta merumus ulang nilai-nilai tersebut dalam konteks kekinian. Meskipun dihadapkan dengan keadaan yang menuntut sistem pendidikan pesantren menyesuaikan diri dengan keadaan sekarang ini yang serba dinamis, tetapi lembaga pesantren tetap dengan sebuah sistem yang mereka bangun dari awal akan tetapi lembaga pesantren tidak menutup diri akan perkembangan zaman mereka juga mencoba mengambil pelajaran agar apa yang di pelajari dan dilakukan di pesantren bisa di aktualisasikan di tengah-tengah masyarakat sekarang ini.

Dari pokok pernyataan di atas, penulis meneliti lebih dalam lagi tentang pemikiran Nurcholish Madjid yang berkaitan dengan modernisasi pendidikan pesantren, dan penelitian ini berjudul "Modernisasi Pendidikan Pesantren Perspektif Nurcholish Madjid", tinjauan untuk mencari dan menggali dengan sedalam-dalamnya ide dan pemikiran Nurcholish madjid yang berkaitan dengan pembaharuan pendidikan pesantren.

\section{Pembatasan Masalah}

Untuk mendapatkan data yang valid dan relevan dan agar tidak melebar kemana-mana serta untuk mempermudah di dalam memahami penelitian ini, penulis membatasi pokok pembahasan masalah pada konsep modernisasi pendidikan pesantren perspektif Nurcholish Madjid, tujuan, dan serta dasar-dasar yang mendasari pemikiran ini.

\section{Rumusan Masalah}

Berdasarkan latar belakang masalah di atas, yang menjadi pokok masalah dan yang akan diteliti oleh penulis ini secara khusus dapat dirumuskan sebagai berikut:

a. Bagaimana modernisasi pendidikan pesantren menurut Nurcholish Madjid?

b. Bagaimana hambatan yang dihadapi pendidikan pesantren menurut Nurcholis Madjid?

c. Bagaimana solusi Nurcholis Madjid dalam mengatasi masalah pendidikan pesantren?

\section{METODE}

Pada dasarnya definisi yang dikemukakan oleh pakar peneliti diatas adalah sama, di mana yang dimaksudkan adalah penelitian yang menganjurkan penulis untuk memahami dan melakukan penelitian berdasarkan sumber dan data yang berasal dari dokumen-dokumen tertentu dan penulis dianjurkan untuk menggambarkan secara deskriptif dari data-data yang sudah diperoleh sehingga menghasilkan sebuah narasi yang dilengkapi dengan data-data yang akurat. Sedangkan deskriptif yang dimaksud adalah penelitian yang menguraikan secara teratur seluruh konsep yang dikemukakan oleh tokoh yang akan diteliti.

Berdasarkan penjelasan di atas maka jenis penelitian yang peneliti gunakan adalah jenis penelitian kajian pustaka (library research), yaitu penelitian yang dilaksanakan dengan menggunakan kepustakaan (literature), baik berupa buku, catatan, maupun laporan hasil penelitian dari peneliti terdahulu. Adapun rancangan penelitiannya adalah sebagai berikut:

1. Menelaah modernisasi pendidikan pesantren untuk mereflesikan perkembangan pendidikan sesuai dengan dialektika perkembangan zaman. Konsep-konsep ini ditelaah dari buku-buku yang menjadi sumber dan data yang berkaitan dengan judul penulisan.

2. Menelaah pemikiran Nurcholish Madjid tentang pemikiran modernisasi pendidikan pesantren beserta dasar-dasar yang melandasinya. Dan menganalisis data yang telah diperoleh.

\section{Sumber Data}

Dalam kamus ilmiah populer dijelaskan bahwa data diartikan sebagai kenyataan; fakta atau keterangan atau bahan dasar yang dipergunakan untuk menyusun hipotesa. Sedangkan dalam ka- 
mus lengkap bahasa Indonesia, data diartikan sebagai kata benda (nomina) yang berarti: bahanbahan, pendapatan, keterangan.

Dari sini bisa ditarik garis besar akan arti data yakni sumber bahan yang di dalamnya terdapat fakta atau keterangan yang dapat digunakan untuk menyusun hipotesa. Karena penelitian ini berbentuk kajian pustaka (library research), maka dalam pengumpulan data ini peneliti menggunakan metode dokumentasi. Suharsimi menjelaskan bahwa metode dokumentasi adalah mencari data mengenai hal-hal atau variabel yang berupa catatan, transkip, buku, surat kabar, majalah, prasasti, notulen dan sebagainya.

Jadi yang dimaksud dengan data dan sumber adalah sebuah bahan yang digunakan peneliti dalam melengkapi penelitian yang dilakukannya, sehingga dapat menghasilkan penelitian atau karya ilmiah yang sesuai dengan prosedur penelitian dan dapat dikatakan sebagai karya ilmiah karena data yang diambil merupakan data yang valid dan akurat, serta dapat dipertanggung jawabkan. Dan data yang dipakai dalam penelitian library research ini dapat dikelompokkan menjadi dua, yaitu sumber primer dan sumber sekunder.

\section{a. Sumber Primer}

Yang dimaksud dengan sumber primer dalam penelitian ini adalah karya-karya yang ditulis langsung oleh Nurcholish Madjid. Untuk melihat konsep pendidikan Pesantren menurut Nurcholish Madjid, maka peneliti melakukan survei kepustakaan tentang pemikiran Nurcholish Madjid. Dari hasil survei tersebut, maka peneliti memilih sumber primer yang digunakan dalam penelitian ini yakni buku yang berjudul Bilik-Bilik Pesantren karya Nurcholish Madjid.

\section{b. Sumber sekunder}

Yang dimaksud dengan sumber sekunder adalah karya-karya atau buku yang memiliki kesamaan pemikiran tentang pendidikan pesantren dengan tujuan untuk mempermudah dan memperkuat isi tulisan dalam skripsi ini. Diantaranya buku Ensiklopedia Nurcholish Madjid, Membaca Nurcholis Madjid, Islam Kemoderenan dan Keindonesiaan, Islam Doktrin dan Peradaban, Islam Agama Kemanusiaan, Masyarakat Religius, serta buku-buku yang dapat dijadikan penunjang dalam penulisan skripsi ini. Pentingnya sumber data sekunder dalam penelitian ini adalah untuk menganalisis lebih mendalam dalam meneliti konsep modernisasi pendidikan Pesantren Perspektif Nurcholish Madjid.

\section{Instrument Penelitian}

Pengumpulan data adalah prosedur yang bersifat sistematis dan standar untuk memperoleh data yang diperlukan dalam melakukan suatu penelitian karya ilmiah dan pengumpulan data merupakan prosedur yang sangat penting dalam suatu penelitian.

Oleh karena itu seorang peneliti harus teliti dan terampil dalam mengumpulkan data sehingga data yang dikumpulkan menjadi data yang valid. Untuk mengetahui dan memperoleh data yang valid, khususnya data yang berkaitan dengan pembahasan skripsi ini maka diperlukan bagi peneliti untuk menggunakan dan menerapkan beberapa teknik pengumpulan data, agar kemudian penulisan ini dapat dipertanggung jawabkan secara ilmiah dan rasional sesuai standar tulisan.

Adapun teknik pengumpulan data yang dimaksudkan peneliti adalah dengan menggunakan metode dokumentasi, yang menurut Suharsimi adalah mencari data mengenai halhal atau variabel yang berupa catatan, transkip buku, surat kabar, majalah, prasasti, notulen dan lain sebagainya. Dan data merupakan bagian terpenting dalam suatu penelitian, untuk kegiatan pengumpulan data ini peneliti akan berusaha memperoleh dan mengumpulkan data sebanyakbanyaknya, dan peneliti akan melakukan identifikasi atasnya. Bisa disimpulkan hal-hal yang dilakukan dalam pengumpulan data ini melalui langkah-langkah sebagai berikut:

a. Mengumpulkan data-data yang ada baik melalui buku-buku, dokumen, majalah internet (Browsing), dan lain sebagainya.

b. Menganalisa data-data tersebut sehingga peneliti bisa menyimpulkan tentang masalah yang dikaji.

\section{HASIL dan PEMBAHASAN}

\section{Mengenal Nurcholish Madjid}

a. Biografi

Nurcholish Madjid atau yang biasa dipanggil Cak Nur (Sapaan akrab Nurcholish Madjid) lahir di Jombang, Jawa Timur, 17 Maret 1939, bertepatan dengan tanggal 26 Muharram 1358 $\mathrm{H}$. Nurcholish Madjid adalah putra dari seorang petani Jombang yang bernama KH. Abdul Madjid. Abdul Madjid adalah seorang ayah yang rajin dan ulet dalam mendidik putranya dia adalah seorang figur ayah yang alim. Dia merupakan Kyai alim alumni pesantren Tebuireng dan termasuk dalam keluarga besar Nahdlatul Ulama (NU), yang secara personal memiliki hubungan khusus dengan K.H Hasyim Asy'ari, salah seorang founding father Nahdlatul Ulama. KH. Abdul Madjid inilah yang menanamkan nilai-nilai keagamaan kepada Nurcholish Madjid semenjak dirinya masih berusia 6 tahun.

Dalam mempersepsikan tatanan pendidikan yang diberikan oleh ayahnya, Nurcholish Madjid mencatat: Meskipun pendidikan resmi 
Abdul Madjid hanya tamatan SR, tetapi ia memiliki pengetahuan yang luas. Fasih dalam bahasa Arab dan mengakar dalam tradisi pesantren. Abdul Madjid sering dipanggil "kyai haji", sebagai penghormatan atas ketinggian ilmu keislaman yang dimilikinya, walaupun ia sendiri secara pribadi tidak pernah menyebut diri sebagai kyai dan tidak pernah secara resmi bergabung dengan kalangan ulama. Dan meskipun ia tetap menyebut diri sebagai orang biasa, namun hal itu tidaklah membendung keinginannya untuk mendirikan sebuah madrasah.

Bahkan ia menjadi pengelola utama pada pembangunan madrasah yang ia kelola sendiri dan juga yang paling berperan dalam membesarkan madrasah wathoniyah di Mojoanyar Jombang. Penanaman nilai-nilai keagamaan yang ditanamkan oleh KH Abdul Madjid kepada Nurcholish Madjid, bukan saja melalui penanaman aqidah, moral, etika, atau pun dengan pembelajaran membaca al-Qur'an saja, akan tetapi juga dengan arah pendidikan formal bagi Nurcholish Madjid. Pendidikan dasar yang ditempuhnya pada dua sekolah tingkat dasar, yaitu di Madrasah al-Wathoniyah dikelola oleh ayahnya sendiri dan di Sekolah Rakyat (SR) di Mojoanyar, Jombang.

Pemikiran Nurcholish Madjid yang sedemikian rupa tentu tidak lepas dari pengaruh lingkungan rumah dan eksistensi keluarga serta pengaruh terbesarnya terletak pada asuhan yang diberikan oleh sang ayah. Jadi, sejak tingkat dasar, Nurcholish Madjid telah mengenal dua model pendidikan. Pertama, pendidikan dengan pola madrasah, yang sarat dengan penggunaan kitab kuning sebagai bahan rujukannya. Kedua, Nurcholish Madjid juga memperoleh pendidikan umum secara memadai, sekaligus berkenalan dengan metode pengajaran modern. Pada masa pendidikan dasar ini, khususnya di Madrasah Wathoniyah, Nurcolish Madjid sudah menampakkan kecerdasannya dengan berkali-kali menerima penghargaan atas prestasinya.

Selepas menamatkan pendidikan dasarnya di Sekolah Rakyat (SR) dan Madrasah Ibtidaiyah (MI) pada tahun 1952, Nurcholish Madjid melanjutkan pendidikannya pada jenjang yang lebih tinggi. Pesantren Darul 'Ulum Jombang menjadi pilihan ayahnya dan dipatuhi oleh Nurcholish Madjid. Di pesantren ini Nurcholish Madjid hanya mampu menjalani proses belajarnya selama dua tahun. Atas izin ayahnya, kemudian Nurcholish Madjid pindah ke Pondok Pesantren Darussalam, KMI (Kulliyat Mu'alimien al Islamiah) Gontor Ponorogo pada tahun 1955. hal ini disebabkan penderitaan yang dialami Nurcholish Madjid karena ejekan yang datang dari teman-temannya, terkait dengan pendirian politik ayahnya yang terlibat di Masyumi.

Di Gontor, Nurcholish Madjid selalu menunjukkan prestasi yang baik, sehingga dari kelas 1 ia langsung bisa loncat ke kelas 3. Di pesantren ini, ia banyak mempelajari bahasa asing terutama Bahasa Arab. Sehubungan dengan kemampuan berbahasa Arab ini, terdapat suatu cerita menarik dari Nurcholish Madjid (untuk selanjutnya ditulis dengan nama akrabnya, Cak Nur).

Suatu hari ia pulang ke rumah, Ayahnya, Abdul Madjid dikenal memiliki koleksi kitab yang banyak dan tidak ada yang bisa membaca selain ayahnya sendiri. Ketika pulang ke rumahnya, ditunjukkan beberapa kitab berbahasa Arab dari Mesir dan ayahnya tidak bisa membaca. Sementara Cak Nur mampu membaca kitab-kitab ayahnya itu dengan baik.

Pada waktu itu pondok pesantren Gontor adalah satu satunnya pesantren di pulau Jawa yang telah menerapkan sistem pendidikan modern (dalam proses belajar mengajar tidak lagi menggunakan sistem tradisional, seperti sorogan). Selama belajar di pondok pesantren Gontor, yang terkenal dengan sistem pendidikannya yang diorientasikan pada sikap mandiri dan kemampuan untuk menguasai bahasa asing (bahasa Arab dan Ingris), Cak Nur merasa enjoy dan kerasan. Disana ia mendapatkan pengalaman baru dalam praktik keagamaan.

Kurikulum yang diberikan Gontor menghadirkan perpaduan yang liberal, yakni tradisi belajar klasik dengan gaya modern Barat. Para santri diwajibkan menggunakan Bahasa Arab dan Bahasa Inggris secara aktif dalam berkomunikasi antar santri di lingkungan pesantren. Pelajaran agama yang diajarkan dengan menggunakan bahasa Arab sebagai bahasa pengantarnya di semua kelas kecuali kelas tahun pertama. Tujuan Penekanan pada santri-santri dalam menggunakan kedua bahasa tersebut sebagai bahasa pengantar sehari-hari, yakni mengantarkan para santrinya ke dalam cakrawala pengetahuan yang lebih luas.

Semboyan Gontor yang berbunyi "berbudi tinggi, berbadan sehat, berpengetahuan luas dan berpikiran bebas" memberikan penekanan keseimbangan antara kesehatan jasmani dan rohani, menciptakan iklim yang kondusif bagi santrinya untuk pemikiran kritis dan maju secara intelektual. Di pesantern inilah Nurcholish Madjid masuk ke KMI (Kulliyatul Mu'alimien alIslamiah) selama enam tahun. Pada tahun 1960 Nurcholish Madjid menyelesaikan studi di Gontor dan untuk beberapa tahun ia mengajar di bekas almamaternya. Pondok pesantren Gontor dan orang tuanyalah yang merupakan unsur yang cukup berpengaruh dalam perkembangan intelektual Nurcholish Madjid. 
Perkembangan intelektual Nurcholish Madjid di Gontor berjalan seiring dengan besarnya perhatian orang tuanya $\mathrm{H}$. Abdul Madjid dalam mendidik. Untuk itulah akselerasi belajar yang diperolehnya tersebut menghantarkannya sebagai santri berprestasi. Prestasi belajar Cak Nur yang fenomenal itu, diperhatikan oleh $\mathrm{KH}$. Zarkasyi, salah satu pengasuh pesantren Gontor, dan ketika tamat pada tahun 1960, sang guru bermaksud mengirimkannya ke Universitas alAzhar, Kairo Mesir. Karena waktu itu di Mesir terjadi krisis politik akibat problem Terusan Suez, keberangkatan Cak Nur ke Mesir tertunda, dan untuk sementara waktu Cak Nur mengajar di almamaternya. Ketika terbetik kabar bahwa di Mesir sulit memperoleh visa, sang guru tahu bahwa Cak Nur sangat kecewa dan untuk menghiburnya, KH. Zarkasyi mengirim surat ke IAIN Jakarta meminta agar murid kesayangannya itu dapat diterima, dan dengan bantuan alumni Gontor di IAIN tersebut, Cak Nur bisa diterima, meski tanpa ijazah negeri.

Atas petunjuk gurunya $\mathrm{KH}$. Zarkasyi inilah Nurcholish Madjid meneguhkan pilihannya untuk melanjutkan studi di IAIN Syarif Hidayatullah Jakarta. Pilihannya terhadap IAIN Syarif Hidayatullah Jakarta berkaitan erat dengan minatnya yang besar terhadap pemikiran keislaman. Pemikirannya yang kritis dan keberanian pengembaraan intelektualitasnya ditunjukkan ketika ia menulis skripsi yang berjudul Al-Quran 'Arabiyun Lughatan Wa 'Alamiyun Ma'nan (AlQuran secara Bahasa adalah Bahasa Arab, secara Makna adalah Universal). Tema skripsi yang diangkat oleh Nurcholish Madjid tersebut setidaknya telah menyiratkan kekritisan dan corak berpikir keislaman yang inklusif. Kuliahnya diselesaikan pada tahun 1968 dengan prediket cum laude.

Ketika di Jakarta, sembari kuliah di IAIN Syarif Hidayatullah, Nurcholish Madjid tinggal di Masjid Agung al-Azhar, Kebayoran Baru dan sedemikian Akrab dengan Buya Hamka dan ia sedemikian kagum terhadap dakwah Buya yang mampu mempertemukan pandangan kesufian, wawasan budaya dan semangat al-Qur'an sehingga paham keislaman yang ditawarkan Buya sangat menyentuh dan efektif untuk masyarakat Islam kota.

Minat Nurcholis Madjid terhadap kajian keislaman semakin mengkristal dengan keterlibatannya di HMI. Dia terpilih menjadi Ketua Umum Pengurus Besar HMI selama dua periode berturut-turut dari tahun 1966-1969 hingga 1969-1971. Ia pun menjadi presiden Persatuan Mahasiswa Islam Asia Tenggara (PEMIAT) periode 1967-1969. Dan untuk masa bakti 1969-1971, Cak Nur menjadi Wakil Sekretaris Umum International Islamic Federation of Students Orga- nisation (IIFSO).

Pada tahun 1984, ia berhasil menyandang gelar philosophy Doctoral (Ph.D) di Universitas Chicago dengan nilai cum laude. Adapun disertasinya ia mengangkat pemikiran Ibnu Taymiah dengan judul "Ibn Taymiyah dalam ilmu kalam dan filsafat: masalah akal dan wahyu dalam Islam" (Ibn Taymiyah in Kalam and Falsafah: a Problem of Reason and Revelation in Islam). Disertasi doktoral yang dilakukan ini menunjukkan atas kekaguman dirinya terhadap tokoh tersebut. Kekaguman ini pun menjadi pengakuan yang disampaikannya.

Nurcolish Madjid bukan hanya memiliki prestasi akademik yang menakjubkan, tapi sebagai seorang aktivis-pun ia dipercaya untuk menempati posisi penting pada berbagai organisasi kepemudaan. Ini menyiratkan dedikasinya dalam me-manage waktu antara aktivitas akademik dengan aktivitas organisasinya, hal mana sulit dilakukan oleh rekan-rekan aktivis lainnya. Pada saat yang bersamaan Nurcholish Madjid telah mampu membuktikan integritasnya sebagai intelektual yang produktif.

Kelincahan Nurcholish Madjid di dunia organisasi selama menjadi mahasiswa tidak terlepas dari pengaruh sosiologis dan ideologis KMI Gontor, tempat ia mengenyam pendidikan keagamaan. KMI Gontor bukan saja berbentuk pesantren yang semata-mata menyuguhi para santrinya materi keagamaan klasik an sich, tidak hanya menyuguhi para santrinya untuk menguasai materi pelajaran di kelas, tetapi lebih dari itu semua, Gontor merupakan pesantren modern yang mengajarkan mereka bagaimana cara berorganisasi dengan baik. Hal itulah yang dirasakan oleh Nurcholish Madjid.

Selama di KMI Gontor, Nurcholish Madjid sudah terbiasa dengan dinamika keilmuan, aktivitas keorganisasian, yang karenanya, ia begitu berwujud sebagai mediator kepemimpinan tatkala terjun di HMI (Himpunan Mahasiswa Islam) selama berkiprah di dunia kampus. Dalam menjalankan roda organisasi Nurcholish Madjid banyak menerapkan komitmen ke-KMIannya yang memang diajarkan oleh para pengasuhnya.

Di organisasi HMI ini, Nurcholish Madjid akhirnya terpilih sebagai ketua umum PB HMI untuk dua tahun berturut-turut yakni periode 1966 sampai 1969 dan periode 1969 sampai 1971. Berkat kepiawaiannya sebagai mantan ketua umum PBHMI, selama menjadi mahasiswa di Amerika ia pun dipercaya untuk menjadi presiden persatuan mahasiswa Islam Asia Tenggara (PEMIAT) pada tahun 1967-1969 dan berikutnya ia dipercaya pula untuk menjabat sebagai wakil Sekjen IIFSO (International Islamic Federation of Student Organization/ Federasi Organisasi- 
Organisasi Mahasiswa Islam Internasional) pada tahun 1967-1971.

Dalam perkembangan karirnya, Nurcholish Madjid menduduki beberapa posisi sentral. Di antara beberapa karir sentral yang dicapainya adalah; menjadi staf pengajar di IAIN Syarif Hidayatullah Ciputat Jakarta tahun 1972-1974, menjadi pemimpin umum majalah Mimbar Jakarta tahun 1971-1974, dan juga menjadi pemimpin redaksi majalah Forum. Bersama teman-temannya, ia mendirikan dan memimpin LSIK (Lembaga Studi Ilmu-ilmu Kemasyarakatan), pada tahun 1972-1976 dan LKIS (Lembaga Kebijakan Islam Samanhudi) tahun 1974-1977.

Pada tanggal 3 Januari 1970, dalam acara malam silaturrahmi organisasi pemuda, pelajar, mahasiswa dan sarjana muslim yang tergabung dalam HMI, GPI (Gerakan Pemuda Islam), PII (Pelajar Islam Indonesia) dan Persami (Persatuan Sarjana Muslim Indonesia) Nurcholish Madjid menggantikan pidatonya Dr. Alfian yang berhalangan datang. Pidato yang disampaikannya dalam acara besar tersebut berjudul "Keharusan Pembaharuan Pemikiran Islam dan Masalah Integrasi Umat".

Dari pidato yang disampaikannya ini Nurcholish Madjid mulai menuai pandangan yang sangat kontroversial termasuk dari para seniornya, semisal. Rasjidi, dikarenakan anjurannya terhadap sekularisasi. Isi pembahasan dari judul pidato, "Keharusan Pembaharuan Pemikiran Islam dan Masalah Integrasi Umat" yakni mencakup; Islam Yes, Partai Islam No; kuantitas versus kualitas, liberalisasi pandangan terhadap ajaran Islam sekarang (sekularisasi, kebebasan berpikir, idea of progress, dan sikap terbuka), dan perlunya kelompok pembaharuan "liberal".

Pemikiran Nurcholish Madjid dimulai dari penyampaian pidatonya pada acara HUT ke-3 HMI di Jakarta, 5 Pebruari 1970, dengan judul "pembaharuan pemikiran dalam Islam". Kegigihannya untuk mengembangkan polapola penyegaran paham keagamaan Islam dilakukannya pada saat memberikan kuliah di pusat kesenian Jakarta, 30 Oktober 1972, dengan judul "Menyegarkan Paham Keagamaan di Kalangan Umat Islam Indonesia".

Dunia formal yang ia jalani selama kurun waktu 36 tahun sejak tahun 1984, penuh dengan segudang pengalaman dan prestasi akademik yang sanggat memuaskan. Hal tersebut dibuktikan oleh Nurcholish Madjid dengan prediket cum laude yang setidaknya dapat dijadikan tolak ukur dari kapasitas intelektualnya. Karir Nurcholish Madjid semakin sempurna tatkala ia dinobatkan sebagai Guru besar IAIN Syarif Hidayatullah Jakarta sebagai rasa penghargaan pihak kampus baginya yang begitu lama menggeluti dunia keilmuan pada tangggl 10 Agustus 1998.

Adapun pidato pengukuhannya sebagai guru besar berjudul "Kalam Kekhalifahan Manusia Reformasi: Suatu Percobaan Pendekatan Sistematis Terhadap Konsep Antropologis Islam". Dialah yang sering dimintai nasihat oleh Presiden Soeharto terutama dalam mengatasi gejolak pasca kerusuhan Mei 1998 di Jakarta setelah Indonesia dilanda krisis hebat yang merupakan imbas krisis 1997.

Ide dan Gagasan Cak Nur tentang sekularisasi dan pluralisme tidak sepenuhnya diterima dengan baik di kalangan masyarakat Islam Indonesia.Terutama di kalangan masyarakat Islam yang menganut paham tekstualisliteralis pada sumber ajaran Islam. Mereka menganggap bahwa paham Cak Nur dan Paramadinanya telah menyimpang dari teks-teks Al-Qur'an dan AlSunnah.

Gagasan yang paling dianggap kontroversial adalah ketika Cak Nur menyatakan "Islam Yes, Partai Islam No," sementara dalam waktu yang bersamaan sebagian masyarakat Islam sedang gandrung untuk berjuang mendirikan kembali partai-partai yang berlabelkan Islam. Konsistensi gagasan ini tidak pernah berubah ketika setelah terjadi reformasi dan terbukanya kran untuk membentuk partai yang berlabelkan agama.

Cak Nur tutup usia pada hari Senin tanggal 29 Agustus $2005 \mathrm{M}$ atau bertepatan dengan tanggal 24 Rajab $1426 \mathrm{H}$ pukul 14.05 WIB, ia kembali ke pangkuan Ilahi karena penyakit hati yang dideritanya. Suami Omy Komariyah ini disemayamkan di Taman Makam Pahlawan Kalibata, Meskipun merupakan warga sipil, ia dikebumikan di Makam Pahlawan karena dianggap telah banyak berjasa kepada negara.

Organisasi, jabatan, dan karier yang pernah diamanatkan Nurcholish Madjid adalah: Peneliti Lembaga Penelitian Ekonomi dan Sosial (LEKNASLIPI), Jakarta 1978-1984, Profesor Tamu, McGill University, Montreal, Kanada, 1991-1992, Wakil Ketua Dewan Penasehat Ikatan Cendekiawan Muslim Indonesia (ICMI), 19901995, Anggota Dewan Penasihat ICM, 1996, Penerima Cultural Award ICM, 1995, Anggota MPR-RI 1987-1992 dan1992-1997, Anggota Dewan Pers Nasional, 1990-1998, Penerima Bintang Mahaputra, Jakarta 1998, Fellow, Eisenhower Fellowship, Philadelphia,Amerika Serikat, 1990, Peneliti Senior, Lembaga Ilmu Pengetahuan Indonesia (LIPI), Jakarta, 1984-2005, Dosen, Fakultas Pasca Sarjana, Institut Agama Islam Negeri (IAIN) Syarif Hidayatullah Jakarta 19852005, Anggota KOMNAS HAM, 1993-2005, Rektor, Universitas Paramadina Mulya, Jakarta, 1998-2005. 


\section{Karya-karya tulis Intelektual Nurcholis Madjid}

Karya-karya Aktifitas Nurcholish Madjid (semasa hidupnya) yang begitu padat tidak menyurutkan kreatifitasnya untuk menulis dan meneliti berbagai persoalan yang berkembang dalam masyarakat. Pada umumnya karya-karya tersebut tertuang dalam bentuk buku, jurnal, buletin, majalah, dan lainnya.

Latar belakang pendidikan yang ditempuhnya mampu mengantarakan arah pemikirannya kepada wawasan yang berlandaskan nilainilai keislaman, khususnya dalam bidang pendidikan agama (Islam). Sebagai sosok pemikir, Nurcholish Madjid sering menuangkan gagasan dan pemikirannya yang bersifat konstruktif dan kemodernan (walaupun terkadang mengundang kontroversial di sebagian masyarakat) mengenai pola kehidupan masyarakat saat ini, khususnya yang berkaitan dengan pendidikan agama dalam keluarga yang selama ini dianggap masih jauh dari nilai ketuhanan, yakni pendidikan agama dalam keluarga yang memposisikan orang tua dan anggota keluarga lainnya sebagai sebuah sistem yang kurang seimbang.

Sehingga anak yang seharusnya mendapatkan tulada, contoh baik dari orang tua menjadi kurang efektif dan cenderung cuek (masa bodoh). Orang tua merasa cukup dengan pendidikan yang diberikan oleh sekolah, mushalah, masjid dan sejenisnya.

Dari sinilah muncul gagasannya tentang pola pendidikan keluarga yang seimbang, baik ditinjau dari polahubungan antara orang tua dan anak, anggota keluarga satu dengan anggota keluarga yang lain, antara anak dengan tetangga, dan antara keluarga dengan masyarakat luas. Kaitannya dengan pembahasan ini, Nurcholish Madjid menyoroti tentang sosok keluarga (orang tua) yang dipandang sebagai pengemban amanah yang harus menjalankan amanahnya dengan sikap tunduk dan patuh terhadap ketentuan Allah SWT.

Dalam pandangannya, pendidikan agama dalam keluarga harus ditanamkan kepada anak sejak dini, bahkan dimulai sejak memilih pasangan hidup. Dengan demikian diharapkan dapat mengantarkan anak menjadi hamba Allah, Abdullah, dalam rangka menjadi wakil Allah, khalifatullah di muka bumi. Gagasan Nurcholish Madjid tentang pendidikan agama dalam keluarga sebenarnya merupakan kajian sosial-keagamaan yang notabene bernuansa Islamis-humanis, karena pola pikir yang dijadikan landasan adalah bersumber dari Islam itu sendiri serta wawasan yang bernilai kemanusiaan dan keagamaan.

Nurcholish Madjid adalah seorang dari sedikit intelektual muslim Indonesia dan men- jadi orang nomor satu di Paramadina. Ia dilahirkan dari kalangan Islam tradisionalis yang kuat. Nurcholish Madjid sejak memperoleh pendidikan di Pesantren Gontor, yaitu pesantren yang menerapkan semboyan "berpikir bebas setelah berbudi tinggi, berbadan sehat dan berpengetahuan luas", sangat mempengaruhi pemikirannya untuk tidak memihak pada salah satu madzhab Islam.

Pada saat Nurcholish Madjid masih aktif dalam Himpunan Mahasiswa Islam Indonesia (HMI), satu periode di mana Republik Indonesia sedang bergejolak dan merupakan masa transisi dari rezim lama ke rezim baru yang membawa paradigma baru, termasuk paradigma dalam membangun Indonesia ke depan saat itu yang kemudian menjadi "latar belakang" yang sedikit banyak menjadi variabel signifikan bagi lahirnya gagasan dan pemikiran keislaman Nurcholish Madjid yang relatif "asing" bagi umat Islam saat itu.

Nurcholish Madjid sejak menjadi mahasiswa telah aktif menulis tentang kajian keislaman maupun politik, sehingga dia sempat mendapatkan gelar "Natsir Muda". Gelar tersebut didapat Nurcholish Madjid dengan ciri khas orang yang anti dan sangat membenci Barat, akan tetapi sikap itu pada akhirnya runtuh ketika Nurcholish Madjid usai melakukan kunjungannya di Amerika Serikat dan beberapa Negara Timur Tengah yang akhirnya gelar tersebut dicopot.

Pada saat Nurcholish Madjid melaksanakan pendidikan di Chicago, Amerika Serikat, beliau menjadi murid seorang ilmuan muslim ternama neomodernisme dari Pakistan yaitu Fazlur Rahman. Diperguruan inilah Fazlur Rahman mengotak-atik pemikiran Nurcholish Madjid untuk dibawa ke bidang kajian keislaman. Pengaruh Fazlur Rahman terhadap gerakan intelektual Nurcholish Madjid bukan untuk mengubah pola pemikiran Nurcholish Madjid. Hanya saja, bukan mengatakan sama sekali, Fazlur Rahman telah begitu berpengaruh dalam mengantarkan pemikiran Nurcholish Madjid untuk kembali kepada warisan klasik kesarjanaan Islam.

Nurcholish Madjid dapat dikelompokkan pada penulis yang produktif. Sekembalinya dari studi, bersama kawan dan koleganya pada tahun 1986 mendirikan Yayasan Wakaf Paramadina. Di lembaga inilah sebagian besar Nurcholish Madjid mencurahkan hidup dan energi intelektualnya (sehingga pada akhirnya melahirkan Universitas Paramadina Mulya, dengan obsesi mampu menjadi pusat kajian Islam kesohor di dunia) di samping sebagai peneliti LIPI sebagai profesi awalnya dan sekaligus sebagai Profesor Pemikiran Islam di IAIN (kini UIN Syarif Hidayatullah Jakarta). Dalam perjalanan hidupnya, ia telah 
menghasilkan banyak artikel ataupun makalah yang telah dibukukan. Beberapa karyanya antara lain adalah sebagai berikut:

a. Khazanah Intelektual Islam. Karya ini menurut penulisnya dimaksudkan untuk memperkenalkan salah satu aspek kekayaan Islam dalam bidang pemikiran, khususnya yang berkaitan dengan filsafat dan teologi. Dalam buku ini dibahas pemikiran al-Kindi, al-Farabi, Ibn Sina, al-Ghazali, Ibn Rusyd, Ibn Taymiyah, Ibn Khaldun, Jamal al-Din alAfghani dan Muhammad Abduh.

b. Islam Kemodernan dan Keindonesiaan. Dalam buku ini, yang merupakan kumpulan tulisan selama dua dasawarsa melontarkan gagasan Nurcholish Madjid tentang korelasi kemodernan, keislaman dan keindonesiaan, sebagai respon terhadap berbagai persoalan dan isu-isu yang berkembang di saat itu.

c. Islam Doktrin dan Peradaban: Sebuah Telaah Kritis tentang Masalah Keimanan, Kemanusiaan dan Kemodernan. Buku ini merupakan karya monumentalnya pasca studi di Chicago. Dalam buku ini, Cak Nur berusaha mengungkapkan ajaran Islam yang menekankan sikap adil, inklusif dan kosmopolit.

d. Islam Kerakyatan dan Keindonesiaan: Pikiran-Pikiran Nurcholish Madjid "Muda". (1994)

e. Pintu-Pintu Menuju Tuhan (1994). Buku ini merupakan kumpulan sebagian besar tulisan Cak Nur di harian Pelita dan Tempo. Menurut penulisnya, buku ini merupakan penjelasan lebih sederhana dan "ringan" (populer) dari gagasan Islam inklusif dan Universal yang menjadi tema besar buku Islam Doktrin dan Peradaban.

f. Islam Agama Peradaban: Membangun Makna dan Relevansi Doktrin Islam dalam Sejarah (1995). Dalam buku ini pemikiran Cak Nur lebih terarah pada makna dan implikasi penghayatan Iman terhadap perilaku sosial yang senantiasa mendatangkan dampak positif bagi kemajuan peradaban kemanusiaan.

g. Islam Agama Kemanusiaan: Membangun Tradisi dan Visi Baru Islam Indonesia (1995). Buku ini sama dengan karya monumentalnya, hanya saja, Cak Nur menyajikannya dengan wawasan yang lebih kosmopolit dan universal sekaligus mempertimbangkan aspek parsial dan kultural paham-paham keagamaan yang berkembang.

h. Masyarakat Religius (1997). Buku ini mengetengahkan konsep Islam tentang kemasyarakatan, antara komitmen pribadi dan komitmen sosial serta konsep tentang eskatologi dan kekuatan adi-alami. i. Tradisi Islam: Peran dan Fungsinya dalam pembangunan di Indonesia (1997). Dalam buku ini Cak Nur mengetengahkan tentang peran dan fungsi Pancasila, organisasi politik, demokratisasi, demokrasi dan konsep oposisi loyal.

j. Kaki Langit Peradaban Islam (1997), mengetengahkan tentang wawasan peradaban Islam, kontribusi tokoh intelektual Islam semisal Al-Shafi'i dalam bidang hukum, al-Gazali dalam bidang tasawuf, ibn Rusyd dalam filsafat dan Ibn Khaldun dalam filsafat sejarah dan sosiologi.

k. Bilik-Bilik Pesantren: Sebuah potret Perjalanan (1997), yang membahas tentang dinamika pesantren serta kontribusinya dalam peradaban Islam di Indonesia.

1. Dialog Keterbukaan: Artikulasi Nilai Islam dalam Wacana Sosial Politik Kontemporer (1997). Buku yang merupakan transkrip wawancara yang pernah dilakukan oleh Cak Nur memiliki mainstream bagaimana nilainilai universal dan kosmopolit Islam diaktualisasikan dalam praktik politik kontemporer.

m. Cendekiawan dan Religiusitas Masyarakat: Kolom-Kolom di Tabloid "Tekad" (1999). Dalam buku ini Cak Nur berusaha menjelaskan pemikiran-pemikirannya tentang keterkaitan antara dimensi keislaman dengan dimensi keindonesiaan dan kemodernan sekaligus. Buku ini merupakan kumpulan tulisan Cak Nur di Tabloid Tekad yang merupakan suplemen dalam harian Republika, sebuah koran harian yang diterbitkan oleh ICMI (Ikatan Cendekiawan Muslim Indonesia).

n. Cita-cita Politik Islam di Era Reformasi (1999). Buku ini merupakan perjalanan panjang politik Nurcholish Madjid dalam wacana perpolitikan di Indonesia. Dalam buku ini prototype negara Madinah yang telah didirikan Nabi Muhammad sedemikian ditekankan oleh Cak Nur sebagai sesuatu yang sangat cocok untuk diterapkan kini, mengingat nilainilainya sedemikian modern bahkan terlalu modern untuk masanya sehingga tidak bertahan lama.

o. Islam Kemodernan dan Keindonesiaan; Bandung, Mizan, 1988.

p. Buku ini merupakan kumpulan-kumpulan tulisan Nurcholish Madjid yang ditulisnya selama rentang waktu dua dasawarsa. Karya ini tersusun sebagai respon terhadap berbagai persoalan dan isu-isu yang berkembang di sekitar kemodernan, keislaman dan keindonesiaan. Karya ini juga mendapat sambutan antusias dari pembaca, hal ini ditandai 
dengan beberapa kali cetak ulang.

q. Indonesia Kita (2003). Dalam buku yang merupakan karya tulis terakhirnya, Nurcholish Madjid berusaha memahami secara lebih luas dan mendalam tentang hakikat dan persoalan bangsa dan negara Republik Indonesia sejak dari masa lampau sampai sekarang yang menantang. Dalam buku ini dimuat pokok pemikiran Cak Nur ketika mencalonkan diri sebagai Presiden RI yang meskipun kandas melalui konvensi Partai Golkar yang terkenal dengan Sepuluh Platform Membangun Kembali Indonesia.

Di samping itu, terdapat beberapa ceramahnya yang juga dibukukan, seperti Perjalanan Religius Umrah dan Haji; Pesan-Pesan Takwa Nurcholis Madjid: Kumpulan Khutbah Jumiat di Paramadina; 30 Sajian Ruhani: Renungan di Bulan Ramadhan. Pada sisi lain, ia juga banyak menulis artikel yang tersebar di beberapa buku suntingan orang lain, baik dalam bahasa Indonesia maupun bahasa Inggris, yang tersebar di beberapa jurnal nasional maupun jurnal internasional.

Dalam kata pengantarnya Komaruddin Hidayat menyatakan bahwa melalui buku ini Nurcholish Madjid menunjukkan konsistensinya sebagai pemikir yang apresiatif dan memiliki aksesintelektual terhadap khazanah Islam klasik. Namun berbarengan dengan itu ia tetap setiap pada cita-cita humanisme dan modernism Islam. Ditambah lagi dengan wawasan kesejarahan dan sosiologisyang dipelajari telah memungkinkan Nurcholish Madjid untuk menyuguhkan wawasan dan interprestasi ajaran dasar Islam yang terbebas dari mitos pemihakan idiologis karena kepentingan politik praktis.

Selain buku-buku diatas yang sudah dipaparkan, masih banyak pula karya Nurcholis Madjid yang sudah beredar dipasaran dan tidak sempat dalam bab ini. Buku-buku itu diantaranya : pesan-pesan taqwa Nurcholis Madjid, ia juga pernah menterjemahkan buku sunnah dan perannya dalam menetapkan Hukum Islam: sebuh pembelajaran kaum Sunni, karya uatafa al Sibai. Tidak hanya buku, Nurcholis Madjid juga menulis berbagai artikel tentang keislaman, politik Islam, Moral dan sebagainya yang dimuat dalam harian Kompas, Pelita, Suara pembahruan, Republika, Jurnal, Ulumul Qur'an, Panji Masyarakat, Prisma, Amanah, dan lain Sebagainya.

\section{Modernisasi Pendidikan Pesantren pers- pektif Nurcholis Madjid}

Institusi pendidikan di Indonesia yang mengenyam sejarah paling panjang di antaranya adalah pondok pesantren. Institusi ini lahir, tumbuh dan berkembang telah lama. Bahkan, semenjak belum dikenalnya lembaga pendidikan lainnya di Indonesia, pesantren telah hadir lebih awal. Dalam kesejarahannya yang amat panjang itu, pesantren terus berhadapan dengan banyak rintangan, di antaranya pergulatan dengan modernisasi.

Di sini, pondok pesantren tengah berada dalam proses pergumulan antara "identitas dan keterbukaan”. Di satu pihak, pondok pesantren di tuntut untuk menemukan identitasnya kembali sebagai lembaga pendidikan Islam. Sementara di pihak lain, ia juga harus bersedia membuka diri terhadap sistem pendidikan modern yang bersumber dari luar pesantren. Salah satu agenda penting pesantren dalam kehidupan dewasa ini adalah memenuhi tantangan modernisasi yang menuntut tenaga terampil di sektor-sektor kehidupan modern.

Dalam kaitan dengan modernisasi ini, pondok pesantren diharapkan mampu menyumbangkan sumber daya manusia yang dibutuhkan dalam kehidupan modern. Mempertimbangkan proses perubahan di pesantren, tampaknya bahwa hingga dewasa ini pondok pesantren telah memberi kontribusi penting dalam menyelengarakan pendidikan formal dan modern, Abdurrahman wahid (Gus Dur) menegaskan bahwa pesantren pada hakikatnya adalah bersifat dinamis, inklusif (terbuka) pada perubahan, dan mampu menjadi penggerak perubahan yang diinginkan, peneliti mencoba mengembangkan statement tersebut pada 4 (empat) pilar pesantren, yakni pada sistem pendidikan pesantren, kurikulum pesantren, pola pembelajaran pesantren, dan sistem penyelenggaraan pendidikannya. Bagaimanapun kondisi pesantren saat ini merupakan realitas yang tak dapat dihindari atau pun dipungkiri.

Di sadari atau tidak, ekspansi modernisasi berserta dengan semua agenda besarnya telah mengakibatkan berbagai dampak yang tak terkendali, membuat pesantren agak gelimpangan dalam menghadapi masalah yang dihadapinya. Menurut Abdul 'Ala pengadopsian sis' tem madrasi yang klasikal belum sepenuhnya dijalani oleh pesantren sesuai dengan tatanan nilai-nilai yang dianutnya. Akibatnya, di satu sisi pesantren tergiring pada budaya pragmatis. Sedangkan, disisi lain pesantren belum mampu mengintegrasikan antar disiplin ilmu secara untuh dan interdependensi. Pada garis besarnya ide pembaharuan dalam bidang pendidikan yang berkembang di dunia Islam, bisa digolongkan menjadi tiga jenis, yaitu:

a. Pembaharuan pendidikan Islam yang berorientasi pada sistem pendidikan yang berlaku di Barat, yaitu mengembangkan ilmu pengetahuan dan teknologi serta kebudayaan.

b. Pembaharuan pendidikan Islam yang ber- 
orientasi pada ajaran Islam yang murni. Mereka berpandangan bahwa sesungguhnya ajaran Islam sendiri merupakan sumber bagi perkembangan peradaban serta ilmu pengetahuan. Upaya ini diwujudkan dengan kembali kepada sumber ajaran Islam yang murni al Qur'an dan al-Sunnah, yang tidak pernah membedakan antara agama dan ilmu pengetahuan.

c. Gerakan pembaharuan yang berorientasi pada kekuatan-kekuatan dan latar belakang sejarah masing masing. Dengan memperbaiki dan mengembangkan apa yang ada, dengan menghilangkan kelemahan-kelemahannya, serta memasukkan unsur-unsur baru (ilmu pengetahuan dan teknologi) diharapkan akan membawa kemajuan. Ketiga pandangan tersebut nampaknya mempunyai pengaruh terhadap perkembangan dan pembaharuan pesantren dan sistem pendidikan Islam di Indonesia menjelang abad ke-20.

Sistem penyelenggaraan sekolah-sekolah modern klasikal mulai masuk ke dunia pesantren. Sementara itu, di beberapa pesantren mulai memperkenalkan sistem madrasah, sebagaimana sistem yang berlaku di sekolahsekolah umum, tetapi pelajarannya dititik beratkan pada pelajaran agama. Kemudian pada perkembangan berikutnya, madrasah-madrasah yang semata-mata bersifat diniyah berubah menjadi madrasah-madrasah yang mengajarkan dan mengembangkan ilmu pengetahuan umum. Kurikulum yang dianutnya pun menunjukkan wajah serupa. Meski persoalan ini tidak ditunjukkan oleh pesantren, namun orientasi dan visi pesantren tidak harus dibiarkan begitu saja yang berjalan apa adanya. Apalagi kondisi seperti ini lebih diperburuk lagi oleh pola pembelajaran yang cenderung memakai pendekatan searah dan monolog. Akibatya, ajaran Islam yang begitu holistik dan universal, diterima oleh para santri secara parsial dan terpotong-potong.

Akibatnya, aspek kognitif, afektif, dan konatif pada masyarakat santri sulit akan tercapai. Kendatipun lembaga tersebut telah mengikuti warna pembaharuan (pendidikan), tetapi masih saja terdapat sisi-sisi kelemahan dalam pandangan Nurcholish madjid. Nurcholish Madjid sebagai salah seorang santri yang sebagian bersifat terbuka, kosmopolit, dan demokratis mengadakan penelaahan terhadap kondisi dunia pesantren, penelaahan tersebut ditujukan pada kritik pedas yang dilontarkan Nurcholish Madjid terhadap dunia pesantren. Secara terperinci penelaahan Nurcholish Madjid diatas berkisar pada: perumusan tujuan pesantren, penyempitan orientasi kurikulum, dan sisitem nilai di pesantren.

\section{Merumuskan kembali tujuan pendidikan pesantren}

Pendidikan merupakan sebuah proses sehingga pengukuran dari proses pendidikan tersebut adalah bagaimana tujuan pendidikan itu bisa tercapai. Tujuan yang hendak dicapai oleh pendidikan pada hakekatnya merupakan sebuah perwujudan dari nilai-nilai ideal yang yang terbentuk dalam diri manusia. Terbentuknya nilai-nilai tersebut dapat diaplikasikan kedalam perencanaan kurikulum pendidikan sebagai landasan dasar operasional pelaksanaan itu sendiri. Adapun letak ketidakmampuan pendidikan pesantren dalam mengikuti dan menguasai perkembangan zaman adalah lemahnya visi dan tujuan yang dibawa pendidikan pesantren relatif sedikit pesantren yang mampu secara sadar merumuskan tujuan pendidikan serta menuangkannya dalam rencana kerja atau program.

Menurut Nurcholihs Madjid kecendrungan tersebut dikarenakan: "Adanya proses improvisasi yang dipilih sendiri oleh kyai atau bersamasama para pembantunya secara intuitif yang disesuaikan dengan perkembangan pesantrennya. Malahan pada dasarnya memang pesantren itu sendiri dalam semangatnya adalah pancaran kepribadian pendidiknya. Maka tidak heran kalau timbul anggapan bahwa hampir semua pesantren itu merupakan hasil usaha pribadi atau individu (individual enterprise).

Nampaknya Nurcholish Madjid melihat ketidakjelasan arah, sasaran yang ingin dicapai pesantren lebih-lebih disebabkan oleh faktor kyai dalam memainkan peran sentral sebuah pondok pesantren. Kyai yang merupakan elemen yang paling esensial dalam pesantren sudah sewajarnya bahwa pertumbuhan suatu pesantren sematamata bergantung pada kemampuan pribadi kyainya.

Senada dengan hal itu Komaruddin Hidayat mengatakan bahwa: Pesantren dalam melakukan sesuatu biasanya tidak mendasarkan pada strategi dan teori pembangunan yang digariskan pemerintah, melainkan berangkat dari penghayatan dan pemahaman keberagaman sang Kyai yang kemudian direfleksikan dan diaktualisasikan sebagai amal shaleh.

Oleh karena itu, dengan pendekatan normatif dan teoritis dalam mengamati dunia pesantren atas ilmu-ilmu sosial Barat, selalu tidak kena dan tidak mampu merasuki realitas yang lebih dalam dari dunia pesantren.

Sehingga hampir tidak ada rumusan tertulis tentang kurikulum, tujuan, dan sasaran pendidikan pesantren kecuali pada otoritas Kyai. Keberlangsungan sebuah pesantren yang semata-mata otoritas Kyai tersebut menurut 
Nurcholish Madjid punya dampak negatif bagi pesantren dalam perkembangannya. Hal ini berdasarkan atas profil Kyai sebagai pribadi yang punya keterbatasan dan kekurangan. Salah satu keterbatasannya tercermin dalam kemampuan

Berkaitan dengan hal ini Nurcholish Madjid mencontohkan seorang kyai yang kebetulan tidak dapat menulis huruf latin mempunyai kecenderungan lebih besar untuk menolak dan menghambat dimasukkannya pengetahuan bacatulis kedalam kurikulum pesantren. Sehingga tidak heran bila pada gilirannya pesantren hanya melahirkan produk-produk pesantren yang dianggap kurang siap untuk "lebur" dan mewarnai kehidupan modern. Dengan kata lain pesantren hanya mampu memunculkan santrisantri dengan kemampuan yang terbatas.

Disamping itu metode yang digunakan Kyai dalam proses belajar mengajar telah mengabaikan aspek kognitif yang berdampak negatif pada output pesantren itu sendiri. Lebih jauh Nurcholish Madjid menjelaskan: "Pengajian adalah kegiatan penyampaian materi pengajaran oleh seorang Kyai kepada para santrinya. Tetapi dalam pengajian ini ternyata segi kognitifnya tidak cukup diberi tekanan, terbukti dengan tidak adanya sistem kontrol berupa test atau ujian-ujian terhadap penguasaan santri pada pelajaran yang diterimanya.

Disini para santri kurang diberi kesempatan menyampaikan ide-idenya apalagi untuk mengajukan kritik bila menemukan kekeliruan dalam pelajaran sehingga daya dan kreatifitas berpikir mereka agak terlambat". Memang disadari bahwa pendidikan pesantren tersebut hanya menitikberatkan pada aspek kognitif seperti lembaga-lembaga pendidikan modern sekarang, tetapi justru pada aspek afektif dan psikomotorik, jelasnya bagaimana santri mau dan mampu menyadari nilai-nilai ajaran Islam dan menginternalisasikan pada dirinya dan mewujudkan dalam perilaku dan kehidupan. Jika arah dan tujuan pendidikan dianggap titik kelemahan dan kepincangan dalam dunia pesantren. Maka, Nurkholis Madjid mengatakan, hal yang harus dibenahi dalam pesantren adalah bagaiman menyeimbangkan antara tujuan yang bersifat kognitif, afektif, dan psikomotorik.

\section{Penyempitan Orientasi Kurikulum}

Kurikulum merupakan salah satu instrumen dari suatu lembaga pendidikan, termasuk pendidikan pesantren. Untuk mendapatkan gambaran tentang pengertian kurikulum, akan disinggung terlebih dahulu definisi tentang kurikulum. Menurut Iskandar Wiryokusumo, kurikulum adalah Program pendidikan yang disediakan sekolah untuk siswa. Kurikulum adalah suatu rencana yang disusun untuk melancarkan proses belajar-mengajar di bawah bimbingan dan tanggung-jawab sekolah atau lembaga pendidikan beserta staf pengajarnya. Pandangan Nurcholish Madjid tentang kurikulum pendidikan pesantren terlihat bahwa pelajaran agama masih dominan dilingkungan pesantren, bahkan materinya lebih khusus disajikan dalam berbahasa arab. Mata pelaran meliputi: Fiqh, nahwu, aqa'id sharaf, sedangkan tasawuf serta rasa agama (religiusitas) yang merupakan inti dari kurikulum keagamaan cenderung terabaikan.

Istilah pelajaran Nurcholish Madjid mengatakan bahwa: Perkataan "agama" lebih tertuju pada segi formil dan ilmunya saja. Sedangkan "keagamaan" lebih mengenai semangat dan rasa agama (religiusitas). Materi "keagamaan" ini hanya dipelajari sambil lalu saja tidak secara sungguh-sungguh. Padahal justru inilah yang lebih berfungsi dalam masyarakat zaman modern, bukan fiqh atau ilmu kalamnya apalagi nahwusharafnya serta bahasa arabnya. Disisi lain pengetahuan umum nampaknya lebih dilaksanakan secara setengah-setengah, sehingga kemampuan santri biasanya sangat terbatas dan kurang mendapat pengakuan dari masyarakat umum. Secara terperinci Nurcholish Madjid menyebutkan penyempitan orientasi kurikulum pendidikan pesantren tersebut berkisar pada nahwu-sharaf, fiqh, aqa'id, tasawuf, tafsir, hadits, dan bahasa Arab. Dimana penelaahan terhadap ilmu-ilmu tersebut tidak hanya secara gramatiknya saja, tetapi bagaimana menguasai ilmu-ilmu tersebut secara lisan ataupun teks sehingga produk (santri) tidak hanya sebagai konsumen melainkan sebagai produsen.

Dalam menyikapi kurikulum pesantren nampaknya Nurcholish Madjid menekankan agar penerapan kurikulum di pesantren adanya check and balance. Perimbangan antara khasanah Islam klasik, pengetahuan keislaman, dan penegetahuan umum. usaha integrasi kedua sistem ilmu (ilmu agama dan ilmu umum) hanya akan menambah persoalan makin rumit. Ini disebabkan belum tersusunnya konsep ilmu integral yang ilmiah yang mampu mengatasi dikotomi ilmu umum dan agama itu sendiri. Integrasi kurikulum pesantren tidak lebih sebagai penggabungan dua sistem ilmu tanpa konsep. Akibatnya, tujuan praktis untuk meningkatkan daya saing lulusan dengan sekolah umum, menjadi sulit dipenuhi. Apa yang dilakukan beberapa pesantren tersebut adalah agar pesantren tetap terus bertahan dan eksis. Hal ini berarti mereka mengikuti jejak kaum modernis. Pesantren melakukan akomodasi dan penyesuaian tertentu tanpa mengorbankan esensi dan hal-hal lainnya agar eksistensi pesantren tetap dipertahankan. Azumardi Azra 
memandang bahwa : pemasukan ilmu umum dalam pelajaran atau kurikulum pesantren banyak permasalahannya. Muncul persoalan tentang bagaimana secara epistemologis untuk menjelaskan ilmu-ilmu empiris atau ilmu ilmu alam dari kerangka epistimologi Islam tersebut.

Hal ini memang menimbulkan persoalan tersendiri dalam tubuh pesantren yang mengalami modernisasi. Kebanyakan ilmu alam yang mereka (pesantren) masukkan dalam kurikulum tidak mempunyai hubungan dengan Islam. Sebagaimana contoh pada Pondok Modern Gontor salah satunya yang memasukkan kurikulum pelajaran umum, bahasa Inggris. Jelas sekali pelajaran bahasa Inggris tidak ada hubungannya dengan tradisi keilmuan dalam Islam.

Hal ini beda dengan bahasa Arab yang digunakan untuk mempelajari kitab kuning dalam pesantren tradisional. Bahasa Arab mempunyai hubungan yang erat dengan bahasa Al-Qur'an. Apapun itu menurut Nurcholish Madjid dalam tulisannya. "Tidak jarang seorang santri yang telah mondok bertahun-tahun, pulang hanya membawa keahlian mengaji beberapa kitab saja. Jika seorang santri merasa betul-betul menguasai sebuah kitab, dia bisa menghadap kyainya meminta tashih dan ijazah kelulusan. Jika ijazah itu diberikan, maka santri tersebut mempunyai wewenang untuk mengajarkan kitab itu kepada orang lain, dan mulailah dia menjadi seorang kyai baru. Fenomena seperti itu menurut Nurcholish Madjid orientasi kulturnya menjadi lebih kental dan kurang memenuhi perkembangan zaman. Terjadinya integritas keilmuan (ilmu-ilmu umum dan ilmu-ilmu Islam) yang selama ini dianggap tidak dapat dikompromikan. Nampaknya bagi Nurcholish Madjid penggabungan antara bahasa Arab (ilmu Islam) dan bahasa inggris (ilmu umum) melambangkan perpaduan antara unsur islam dan unsur keislaman dan unsur kemodernan. Melihat pemikiran Nurcholish Madjid tersebut nampaknya, hal semacam itulah yang memenuhi selera bagi kaum muslim dalam memasuki era modernisasi saat ini.

\section{Nilai di Pesantren}

Dalam dunia pesantren pelestarian pengajaran kitab-kitab klasik perjalanan terusmenerus dan secara kultural telah menjadi ciri khusus pesantren sampai saat ini. Disini peran kelembangan pesantren dalam meneruskan tradisi keilmuan klasik sangat besar. Pengajaran kitab-kitab klasik tersebut pada gilirannya telah menumbuhkan warna tersendiri dalam bentuk paham dan sistem nilai tertentu. Sistem nilai ini berkembang secara wajar dan mengakar dalam kultur pesantren, baik terbentuk pengajaran kitabkitab klasik, maupun yang lahir dari pengaruh lingkungan pesantren itu sendiri.

Menurut pandangan Nurcholish Madjid dalam tulisannya mengatakan: "Sistem nilai yang digunakan dikalangan pesantren adalah yang berakar dalam agama Islam. Tetapi tidak semua yang berakar dalam agama itu dipakai oleh mereka. Kalangan pesantren itu sendiri, menamakan sistem nilai yang dipakainya itu dengan ungkapan Ahl-u'l- Sunnah wa'i Jama'ah. Kalau kita lihat, Ahl-u 'l-Sunnah wa 'i Jama'ah itu sendiri pertama-tama adalah mengacu pada golongan Sunni.

Maka dalam hal kalam atau ilmu ketuhanan, pesantren mengikuti Madzhab sunni, sebagaimana dirumuskan oleh Abu Hassan Al-Asy'ari, dan kemudian tersebar antara lain melalui karyakarya Imam Ghazali" Meskipun menamakan dirinya Ahl-u'l-Sunnah wal Jama'ah tetapi kaum santri tidak banyak yang menyadari adanya golongan-golongan lain diluar mereka (Ahlus Sunnah wal Jamaiah), kecuali mu'tazilah. Kaum mu'tazilah menjadi target kutukan kalangan pesantren sampai saat ini. Sedangkan golongan syiah yang merupakan gologan terbesar diluar Ahl-u'l-Sunnah wa'I Jama’ah, tidak begitu disadari kehadirannya oleh kaum santri. Sedangkan, perkataan Ahl-u'l-Sunnah wa' Jama'ah itu sendiri ialah para pengikut tradisi Nabi Muhammad dan ijma' ulama.

Definisi ini dapat diartikan suatu golongan yang berpegang teguh pada norma-norma dalam sunnah Rasul dan para Khulafaur Rasyidin dan mengamalkan apa-apa yang telah diamalkan Rasul dan para Sahabatnya. Paham Ahlu'l-Sunnah wal Jama'ah, menjadi ciri utama pesantren di Indonesia dan telah dijadikan pula sebagai sistem nilai yang standar pada setiap yang ada. Untuk memperkuat pendapat Nurcholish Madjid diatas perlu dikemukakan pendapat $\mathrm{KH}$. Bisyri Musthafa yang sebagaimana dikutip oleh Zamakhsyari Dhofier. "Paham Ahl-u 'l-Sunnah wa'I Jama’ah adaah paham yang berpegang teguh kepada tradisi sebagai berikut:

a. Dalam bidang hukum-hukum Islam menganut ajaran-ajaran dari salah satu madzhab empat. Dalam praktek, para kyai adalah penganut kuat dari madzhab Syafi'i.

b. Dalam soal-soal tauhid menganut ajaranajaran Imam Abu Hasan Al-Asyari dan Imam Abu Manshur Al-Maturid.

c. Dalam bidang tasawuf menganut dasar-dasar ajaran Imam Abu Qosim Al-Junaid”.

Penekanan pada nilai-nilai yang dipraktekkan dalam kehidupan sehari-hari tersebut membawa akibat tersendiri yaitu kedangkalan tata nilai, kedangkalan tata nilai ini pada gilirannya menghasilkan sikap hidup yang doktriner, yang menggolongkan manusia kepada dua kelompok 
belaka: pihak kita dan pihak lawan. Dalam bentuknya yang paling buruk, kedangkalan ini dapat dilihat pada sikap angkuh yang sebagian santri, disamping verbalisme yang sangat kaku dan formalistis dalam menilai suatu perbuatan.

Oleh karena itu Nurcholish Madjid mengatakan: "Sudah saatnya meninjau kembali segisegi kebaikan dan kekuatan gerakan-gerakan tasawuf tradisional pesantren serta meneliti segi kelemahannya. Segi positif yang berpengaruh cukup luas dalam pesantren, dapat dilihat dari adanya Kyai atau ulama yang menganut ajaran tertentu, atau mengamalkan wirid-wirid yang hanya diamalkan sendiri. Ajaran-ajaran sufi tersebut membentuk tingkah laku para Kyai.

\section{Hambatan yang Dihadapi Pesantren \\ a. Hambatan-hambatan Pesantren}

Suatu kenyataan yang sederhana tetapi cukup tajam adalah adanya anggapan bahwa perkataan modern itu mempunyai konotasi Barat. Meskipun tidak mutlak benar, kita tidak bisa menyalahkan anggapan ini, karena pada dasarnya masih banyak yang mengakui bahwa nilai-nilai yang dianggap modern itu memang didominasi nilai-nilai Barat. Berpijak dari anggapan tersebut kita digiring untuk mengakui bahwa peradaban modern yang melanda dunia, termasuk Indonesia, adalah hasil inovasi peradaban Barat. Karena itu dikatakan bahwa modernisasi sesungguhnya penghalusan dari pengertian westernisasi.

Tetapi sebetulnya nilai-nilai modern itu bersifat universal, berbeda dengan nilai-nilai Barat yang lokal atau regional saja. Yang menjadi arus bawah dari peradaban modern adalah sesuatu yang bersifat universal, yaitu ilmu pengetahuan dan teknologi, yang menjadi hakikat tantangan di zaman modern. Tantangan yang bersifat khusus Barat adalah hanya akibat sampingan, dan tentunya tidak bisa dilepaskan dari fakta bahwa kepemimpinan dunia saat ini masih didominasi orang-orang Barat. Apabila pesantren diharapkan memberikan responsi atas tantangan-tantangan itu, maka kaitannya ialah dengan dua aspek: yang universal, yaitu ilmu dan teknologi dan yang nasional, yaitu pembangunan di Indonesia. Jika dapat dapat memahami pengertian umum tentang kehidupan modern serta mengetahui bagaimana bentuk-bentuk nyatanya maka harus diakui bahwa memang ada semacam ketidakcocokan antara dunia pesantren dengan dunia luar yang dinilai modern.

Ada dua kondisi objektif yang dihadapi oleh pendidikan pesantren, Pertama, masih terdapatnya ambivelensi orientasi pendidikan. Akibatnya, sampai saat ini masih terdapat kekurangan dalam sistem pendidikan yang diterapkan. Hal itu disebabkan masih terdapatnya anggapan bahwa hal-hal yang terkait dengan soal kemasyarakatan atau keduniawian (muamalah), seperti penguasaan berbagai disiplin ilmu umum (sains), keterampilan dan profesi sekolah semata-mata merupakan garapan khusus sistem pendidikan sekuler. Kedua, adanya pemahaman persial atau dikotomis yang memisahkan antara ilmu agama dan sains.

Kedua permasalahan ini memang sangat klasik dan terkesan usang. Tetapi diakui atau tidak, realitas ini sangat mengganggu keberlangsungan perjalanan pesantren kedepan. Ditambah lagi dengan masih banyaknya permasalahan yang sifatya teknis seperti: kurangnya infrastruktur yang bernyawa hingga infrastruktur yang tidak bernyawa, dalam konteks ini secara garis besar permasalahan pesantren dikelompokkan dalam empat hal, yaitu: pertama, kurikulum pendidikan mencakup literature, model pembelajaran, dan pengembangannya, kedua, sarana dan prasarana seperti perpustakaan, labolatorium, internet, lapangan olah raga, dan yang lainnya, ketiga, wahana pengembangan diri seperti organisasi majalah, seminar dan lainnya, dan keempat, wadah aktualisasi diri ditengah masyarakat, seperti tabligh, khatib, dan lainnya.

\section{Solusi yang ditawarkan oleh Nurcholis Madjid}

Masalah pendidikan pesantren Lembaga pendidikan Islam (pesantren) sebagai lembaga alternatif diharapkan mampu menyiapkan kualitas masyarakat yang bercirikan semangat keterbukaan, egaliter, kosmopolit, demokratis, dan berwawasan luas, baik menyangkut ilmu agama maupun ilmu-ilmu modern. Menyikapi realitas pendidikan saat ini. Nurcholis Madjid tampil memodernisasi pendidikan Islam (pesantren).

Usaha ini dimaksudkan untuk menemukan format pendidikan yang ideal sebagai sistem pendidikan alternatif bangsa indonesia masa depan. Kelebihan dan keunggulan lembaga pendidikan masa lampau dijadikan sebagai kerangka acuan untuk merekonstruksi konsep pendidikan yang dimaksud. Sedang sistem yang lama yang kurang relevan akan ditinggalkan dan dibuang. Salah satu konsep yang mendasar menurut nurcholish Madjid ialah: bagaimana menempatkan kembali ilmu pengetahuan teknologi kedalam daerah pengawasan nilai agama,moral, dan etika. asal mula semua cabang ilmu pengetahuan adalah berpangkal pada ilmu. Ketika para intelektual muslim mampu mengembangkan dan mengislamkan ilmu pengetahuan yang modern itu, dunia islam akan mencapai kemakmuran dalam berbagai bidang, seperti yang dicontohkan pada masa Islam klasik.

Berdasarkan ungkapan diatas, modernisasi 
pendidikan pesantren yang ditawarkan oleh Nurcholish Madjid ialah: konsep keterpaduan antara keislaman, keindonesiaan, dan keilmuan. Hal ini sesuai dengan platform pembaharuan Nurcholihs Madjid sendiri yaitu keindonesiaan, keimanan, dan kemodernan. Menurutnya problem yang ada dalam umat Islam ialah kesenjangan yang cukup parah antara ajaran dan kenyataan. Hal yang paling diperlukan oleh umat Islam melalui sarjananya ialah keberaniaan untuk menelaah kembali ajaran-ajaran Islam yang mapan (sebagai hasil interaksi sosial dalam sejarah), dan mengukurnya kembali dengan yardstrick, sumber suci Islam itu sendiri, yaitu AlQur'an dan Al-Sunah.

Demikian pula dalam menetapkan nilai-nilai modern, harusnya berorientasi pada nilai-nilai besar Islam. Memodernisasi berarti berpikir dan bekerja menurut fitrah atau sunnatullah. Oleh sebab itu, dalam menghadapi tantangan zaman modern dunia pendidikan Islam tidakcukuphanya mengimpor iptek Barat secara mentah-mentah, melainkan melihat pada hubungan antara ilmu dan iman atau iman dan ilmu. Kesadaran akan adanya hubungan tersebut akan mendekatkan orientasi tujuan pendidikan Islam itu sendiri. Karena pendidikan diharuskan menumbuhkan keseimbangan terhadap kepribadian total manusia, yang meliputi spritual, intelektual, imajinatif, fisikal, ilmiah, dan linguistik untuk mencapai kebaikan dan kesempurnaan.

Modernisasi pendidikan Islam (pondok pesantren) yang merupakan perpaduan antara tradisional dan moden diharapkan mampu menjadi sarana yang efektif dalam membentuk manusia modern. Namun bagi Nurcholish Madjid ada hal yang lebih penting dalam hal itu ialah pendidikan Islam diharapkan mampu menyelesaikan masalah moral dan etika ilmu penegetahuan modern. Hal tersebut dilatarbelakangi oleh kekecewaan Nurcholish Madjid terhadap peradaban modern dengan tekhnologi dan ilmu pengetahuannya miskin moral dan etika.

Dalam tulisannya Nurcholish Madjid menyebutkan :"Kini muncul banyak kritikan kepada peradaban modern dengan teknologi dan ilmu pengetahuannya itu. Dari sudut pandang Islam, hanya segi metode dan empirissme ilmu pengetahuan modernlah yang nampaknya absah (valid). Sedangkan dalam hal moral dan etika, ilmu pengetahuan modern amat miskin. Hal ini bisa menjadi sumber ancaman lebih lanjut umat manusia. Disinilah letak inti sumbangan Islam dengan sistem keimanan berdasarkan tauhid itu, kaum muslimin diharapkan mampu menawarkan penyelesaian atas masalah moral dan etika ilmu pengetahuan modern. Manusia harus disadarkan kembali atas fungsinya sebagai ciptaan Tuhan, yang dipilih untuk menjadi khalifahnya, dan harus mampu mempertanggung jawabkan seluruh tindakannya di muka bumi ini kepadanya. Ilmu pengetahuan berasal dari Tuhan, dan harus digunakan dalam semangat mengabdikanya.

Dengan demikian Nurcholish Madjid begitu berobsesi terhadap potensi pendidikan pesantren begitu tinggi dan besar. Dalam hal ini Nurcholish Madjid membandingkan, kalau pendidikan non Islam mampu melahirkan lembaga yang berkualitas, kenapa pendidikan Islam tidak?. Harapan tersebut dilatarbelakangi oleh masyarakat modern (rasional dan ilmiah) tidak akan terwujud tanpa adanya peran yang begitu besar dari pendidikan. Dengan kata lain pendidikan memiliki peran yang strategis dalam membentuk masyarakat modern dalam pengawasan khasanah keislaman. Nampaknya Nurcholish Madjid berobsesi menciptakan suatu sistem pendidikan yang memiliki keterpaduan antara unsur keislaman, keindonesiaan, dan keilmuan, sisitem pendidikan yanng dimaksud tersebut diproyeksikan sebagai alternatif untuk menuju era mutakhir saat ini. Untuk itu, disini penulis memaparkan konsep modernisasi pesantren dalam perspektif Nurcholish Madjid yang tergabung dalam tiga unsur tersebut.

\section{Analisis Pemikiran Nurcholish Madjid}

Dari berbagai pemaparan tentang tawaran konsep modernisasi pendidikan Nurcholish Madjid yang hampir sebagian besar mengerucut pada pembaharuan pesantren, saya rasa sangat relevan jika diterapkan pada saat ini. Hal ini karena, masih banyak pesantren di Indonesia yang masih termajinalkan. Kaum santri yang masih dikonotasikan udik dan tidak intelek. Dengan pembaharuan pendidikan pesantren yang bisa mengintegralkan antara pendidikan umum dan agama bisa diharapkan akan terwujudnya para santri intelek dan siap bersaing di era modernisasi ini. Nurcholish Madjid berpendapat bahwa pesantren berhak lebih baik dan lebih berguna mempertahankan fungsi pokoknya semula, yaitu sebagai tempat menyelenggarakan pendidikan agama.

Namun, mungkin diperlukan suatu tinjauan kembali, sehingga ajaran-ajaran agama yang diberikan kepada setiap pribadi menjadi jawaban yang komprehensif atas persoalan hidup, selain tentu saja disertai pengetahuan seperlunya tentang kewajiban-kewajiban praktik seorang muslim sehari-hari. Pelajaran-pelajaran ini kemungkinan dapat diberikan melalui beberapa cara, diantaranya:

a. Mempelajari al-Quran dengan cara yang sungguh-sungguh daripada yang umumnya dilakukan orang sekarang, yaitu de- 
ngan menitikberatkan pada pemahaman makna dan ajaran-ajaran yang terkandung di dalamnya. Ini memerlukan kemampuan pengajaran yang lebih besar. Yaitu, pengajaran kesatuan tentang ayat-ayat atau surat-surat yang dibacanya dengan menghubungkan dengan ayat dan surat-surat lain. Pelajaran ini mungkin mirip dengan pelajaran tafsir, tapi dapat diberikan tanpa sebuah buku atau kitab tafsir melainkan cukup dengan alQur'an secara langsung.

b. Melalui pertolongan sebuah bahan bacaan atau buku pegangan. Penggunaan cara ini sangat bergantung pada kemampuan para pengajar dalam mengembangkanya secara lebih luas.

c. Selain itu, baik sekali memanfaatkan mata pelajaran lain untuk disisipi pandanganpandangan keagamaan lain. Dan menanamkan kesadaran dan penghargaan yang lebih wajar pada hasil-hasil seni budaya Islam atau untuk menumbuhkan kepekaan rohani, termasuk kepekaan rasa ketuhanan yang menjadi inti rasa keagamaan. Selanjutnya Nurcholish Madjid menganjurkan agar pesantren tanggap akan kebutuhan anak didiknya kelak dengan hubunganya terhadap perkembangan kembali, sehingga ajaranajaran agama yang diberikan kepada setiap pribadi menjadi jawaban yang komprehensif atas persoalan hidup, selain tentu saja disertai pengetahuan seperlunya tentang kewajibankewajiban praktik seorang muslim seharihari. Pelajaran-pelajaran ini kemungkinan dapat diberikan melalui beberapa cara, diantaranya:

1) Mempelajari al-Qur'an dengan cara yang sungguh-sungguh daripada yang umumnya dilakukan orang sekarang, yaitu dengan menitikberatkan pada pemahaman makna dan ajaran-ajaran yang terkandung di dalamnya. Ini memerlukan kemampuan pengajaran yang lebih besar. Yaitu, pengajaran kesatuan tentang ayat-ayat atau surat-surat yang dibacanya dengan menghubungkan dengan ayat dan surat-surat lain. Pelajaran ini mungkin mirip dengan pelajaran tafsir, tapi dapat diberikan tanpa sebuah buku atau kitab tafsir melainkan cukup dengan al-Qur'an secara langsung.

2) Melalui pertolongan sebuah bahan bacaan atau buku pegangan.

Penggunaan cara ini sangat bergantung pada kemampuan para pengajar dalam mengembangkanya secara lebih luas.

3) Selain itu, baik sekali memanfaatkan mata pelajaran lain untuk disisipi pandangan pandangan keagamaan lain. Dan menanamkan kesadaran dan penghargaan yang lebih wajar pada hasil-hasil seni budaya Islam atau untuk menumbuhkan kepekaan rohani, termasuk kepekaan rasa ketuhanan yang menjadi inti rasa keagamaan.

Selanjutnya Nurcholish Madjid menganjurkan agar pesantren tanggap akan kebutuhan anak didiknya kelak dengan hubunganya terhadap perkembangan zaman. Untuk itu pesantren dituntut memberikan pengajaran tidak hanya tentang agama tetapi juga umum, tentunya harus sesuai dengan bakat dan potensi yang dimiliki anak didik. Menurut Nurcholish Madjid ilmu pengetahuan atau science adalah prasarat untuk mewujudkan salah satu diciptakan alam ini, yaitu untuk manfaat manusia. Tetapi, ilmu pengetahuan itu diberikan Allah melalui kegiatan manusia itu sendiri dalam usaha memahami alam raya ini.

Hal ini berbeda dengan wahyu yang diberikan dalam bentuk pengajaran atau wahyu lewat para utusan Allah. Dalam usaha memahami alam sekitarnya itu, manusia harus mengerahkan dan mencurahkan akalnya. Maka alam akan menjadi objek pemahaman sekaligus sumber pelajaran hanya untuk mereka yang berpikir saja, seperti yang Allah firmankan dalam al-Qur'annya.

Artinya: Sesungguhnya dalam penciptaan langit dan bumi, dan silih bergantinya malam dan siang terdapat tanda-tanda bagi orang-orang yang berakal (Q.S Ali Imran: 190).

Bentuk kegiatan memahami akal itu ialah akal ('aql), tidak sebagai kata benda konkret, melainkan sebagai kata benda abstrak atau mashdar dari kata kerja 'aqala-ya'qilu yang (artinya berpikir), jadi berupa kegiatan mempelajari atau memahami. Karna itu, akal bukanlah alat pada manusia utuk "menciptakan" kebenaran, melainkan untuk "memahami" atau bahkan "menemukan" kebenaran yang memang dari semula telah ada dan berfungsi dalam lingkungan diluar diri manusia).

Berdasarkan analisis di atas Penulis berkesimpulan bahwa tujuan pendidikan pesantren adalah membentuk manusia yang memiliki kesadaran tinggi bahwa ajaran Islam merupakan pembelajaran yang menyeluruh. Selain itu, produk pesantren ini diharapkan memiliki kemampuan tinggi untuk melakukan responsi terhadap tantangan-tantangan dan tuntutan-tuntutan hidup dalam konteks ruang dan waktu yang ada (Indonesia dan dunia abad sekarang).

Dari hasil penelitian yang telah diuraikan di atas yakni tentang modernisasi pendidikan pesantren perspektif Nurcholish Madjid, maka pada penulis kemukakan tentang kesimpulankesimpulan yang dapat dipetik dari penulisan ini dan juga saran-saran, dengan harapan penelitian ini dapat bermanfaat dengan dijadikannya sebagai 
tambahan wawasan bagi penulis dan pembaca berikut pengembang ide untuk memajukan pesantren yang ada saat ini dan di kemudian hari.

\section{SIMPULAN}

\section{Kesimpulan}

1. Lembaga pendidikan Islam (pesantren) sebagai lembaga alternatif diharapkan mam$\mathrm{pu}$ menyiapkan kualitas masyarakat yang bercirikan semangat keterbukaan, demokratis, dan berwawasan luas, baik menyangkut ilmu agama maupun ilmu-ilmu modern. Menyikapi realitas pendidikan saat ini. Dari hasil penelitian dapat disimpulkan, bahwa pada perkembangan terakhir dengan berdirinya lembaga-lembaga pendidikan oleh kolonial Belanda (modern) lembaga pendidikan Islam (pesantren) semakin tersurut keberadaannya.

Dan enggan menerima hal-hal yang baru. Berangkat dari fenomena di atas Nurcholish Madjid mengklasifikasikan konsep modernisasi sistem pesantren menjadi tiga bagian, Pertama, Keislaman dengan cara mengislamkan ilmu pengetahuan. Kedua, Keindonesaian menciptakan lembaga pendidikan yang mempunyai kultur asli Indonesia. Ketiga, Keilmuan menghilangkan dualisme pendidikan menjadi tunggal.

2. Ada dua kondisi yang dihadapi oleh pendidikan pesantren yang menjadi hambatan selama ini, pertama, masih terdapat ambilvelensi orientasi pendidikan. Akibatnya, sampai saat ini masih terdapat kekurangan dalam sistem pendidikan yang diterapkan. Hal itu disebabkan masih terdapatnya anggapan bahwa hal-hal yang terkait dengan soal kemasyarakatan atau muamalah, seperti penguasaan disiplin ilmu umum (sains), keterampilan sekolah semata-mata merupakan gagasan khusus sistem pendidikan sekuler. Kedua, adanya pemahaman persial atau dikotomis yang memisahkan antara ilmu agama dan ilmu umum.

3. Tawaran dan solusi yang diberikan cak Nur adalah penertiban manajemen pesantren, merumuskan kembali tujuan pesantren, kurikulum pesantren, sistemnilai pesantren serta penanaman nilai kepada peserta didik agar beriman, berilmu, beramal dan tetap berpegangan pada keindonesian yang ada.

\section{Saran}

1. Hasil dari penulisan skripsi ini harap bisa dijadikan sebagai bahan evaluasi dan acuan untuk melakukan reorientasi dan peningkatan kualitas dalam mengembangkan kuri- kulum pembaharuan pesantren, sehingga harapan untuk memiliki kader santri yang unggul dalam hal-hal yang universal.

2. Penulis penelitian ini sehingga hasil penulisan skripsi ini tidak menutup kemungkinan sangat jauh dari kesempurnaan. Dengan harapan kekurangan yang terdapat dalam penulisan skripsi ini, hendaknya dapat disempurnakan, jika memang ada dikemudian hari penulis skripsi yang sama dengan judul ini dan menjadikan skripsi ini sebagai rujukan atau acuan.

\section{DAFTAR PUSTAKA}

Ali. Muhammad. 2008. Metodologi Penelitian Pendidikan Kuantitatif \& Kualitatif. Jakarta: PT. Raja Grafindo Persada

Arikunto. Suharsimi. 2000. Manajemen Penelitian. Jakarta: PT Rineka Cipta. 2010. Prosedur Penelitian Suatu Pendekatan Praktek. Jakarta: Rineka Cipta.

Azra. Azyumardi. 1999. Esei-Esei Intelektual Muslim dan Pendidikan Islam. Jakarta: Logos Wacana Ilmu.

2001. Pendidikan Islam: Tradisi dan Modernisasi Menuju Milenium Baru. Jakarta: Kalimah.

Barton. Greg. 1999. Gagasan Islam Liberal Di Indonesia: Pemikiran NeoModernisme Nurcholish Madjid.

Bell Greder. Margaret E. 1991. Belajar dan Membelajarkan. Penerjemah Munadir. Jakarta: Rajawali.

Djamarah. Bahri. Syaiful dan Zain. Azwan. 2002. Strategi Belajar Mengajar. Jakarta: Rineka Cipta.

Fajar. A. Malik. 1999. Reorientasi Pendidikan Islam. Jakarta: Fajar Dunia.

Gaus. Ahmad AF. 2010. Api Islam Nurcholish Madjid Jalan Menuju Hidup Seorang Visioner. Jakarta: Kompas.

Gunawan. Ary H. 2000. Sosiologi Pendidikan. Suatu Analisa Sosiologi Tentang Pelbagai Problem Pendidikan. Jakarta: Rineka Cipta.

Hasan. Iqbal. 2002. Pokok-Pokok Materi Metodologi Penelitian dan Aplikasinya. Jakarta: Ghalia Indonesia.

Idrus. Fahmi. t.t. Kamus Besar Bahasa Indonesia. Surabaya: Grafindo Press

Madjid.Nurcholish.1995. Islam AgamaPeradaban: Membangun Makna dan Relevansi Doktrin Islam dalam Sejarah. Jakarta: Paramadina.

1992. Islam Doktrin dan Peradaban: Sebuah telaah kritis tentang masalah keimanan. kemanusiaan dan kemoderenan. Jakarta: Ciputat Press. 1993. Islam Kerakyatan dan 
Keindonesiaan. Bandung: Mizan. 2008. Islam. Kemoderenan dan Keindonesiaan. Bandung : Mizan Media Utama.

2010. Bilik-Bilik Pesantren. Jakarta: Paramadina dan Dian Rakyat. ,2004. Biografi dalam Suratsurat Politik Nurcholish Madjid-Muhamad Roem, Jakarta: Djambatan.

Mahendra. Ihza. Yusril. 1998. Modernisme dan Fundamentalisme dalam Politik Islam. Jakarta : Paramadina..

Malik. Dedy Djamaluddin. Dan Ibrahim. Idi Subandy. 1998. Zaman Baru Islam Indonesia: Pemikiran dan

Moleong. Lexy J. 2009. Metodologi Penelitian Kualitatif. Bandung: Pt Remaja Rosdakarya.

Munawwar-rahman. Budhy. (Penyunting).2011. Ensiklopedi Nurcholish Madjid. Jakarta: Democracy Project. Edisi Digital.

Siti Nadroh, 1999. Wacana Keagamaan dan Politik Nurcholish Madjid, Jakarta: Raja Grafindo Persada,

Partanto. Pius A. dan Al-Barry. Dahlan. t.t. Kamus Ilmiah. Surabaya: Arkola.

Potani. Ahmad. 2003. Modernisasi Pesantren. dalam Meniti Jalan Pendidikan Islam. Jogjakarta: Pustaka Pelajar.

Ridwan. Nur Khalik. 2002. Pluralisme Borjuis: Kritik Atas Nalar Pluralisme Cak Nur. Yogyakarta: Galang Press. .

Sasono. Agus Edi. 1997. Tidak Ada Negara Islam: Surat-Surat Politik Nurcholish MadjidMohamad Roem. Jakarta: Djambatan.

Suardi. Moh. 2012. Pengantar Pendidikan: Teori dan Aplikasi. Jakarta: PT. Indeks.

Sugiyono. 2009. Metode Penelitian Pendidikan. Bandung: Alfabeta.

Tamara. Nasir. M. Dan Taher. Peldi. Elza. 1996. Agama dan Dialog Antar Peradaban. Jakarta : Paramadina.

Yasmadi. 2002. Modernisasi Pesantren. Kritik Nurcholish Madjid terhadap Pendidikan Islam Tradisional. Jakarta: Ciputat Press. 